\title{
Cognitive classification of the names of building materials in Russian and English languages
}

\author{
Nurgizya Khasanova ${ }^{1 *[0000-0002-0947-729 \mathrm{X}]}$, Rozaliya Akhmetgareyeva ${ }^{1[0000-0003-3775-5098]}$, and \\ Ilvira Kuznetsova ${ }^{1}$
}

${ }^{1}$ Kazan State University of Architecture and Engineering, 420043, Zelenaya st., Kazan, Russia

\begin{abstract}
Representation of cognitive area and revealing terminological characteristics of the Russian and English names of building materials (NBMs) determine the topicality of the research and the article's problematic. The authors of the article analyze the Russian and English NBMs and reveal their main stages with the comparative description, and choose the definition of the names, in which the basic word-identifier of the leading cognitive features have been highlighted. These features have become the basics for the formation of the thematic groups. The classification of the names of building materials is formed from five groups: organic materials / orgonicheskie materialy; inorganic materials / neorgonicheskie materialy; metals and metal products / metaly i izdelija iz nih; other building materials / prochie stroitel'nye materialy; properties of building materials / svojstva stroitel'nyh materialov. Properties of building materials is subdivided into models according to their structural characteristics: physical properties / fizicheskie svoystva; mechanical properties / mehanicheskie svojstva; defects / defekty.

Keywords: construction, building materials, group, model, cognitive approach, technical term.
\end{abstract}

\section{Introduction}

The cognitive classification of lexical and phraseological thematic groups and models of terminological systems of various areas and their comparative study gains more importance and becomes a topical direction of Russian and foreign researchers. This is reflected both in works on general terminology of A. V. Spirov [1], S. Khudanpur [2], R. Rosenfeld [3], T. Hoffmann [4], A Katherine [5] and in studies on theoretical problems of language classification of Z. T. J. Kamali [6], M. Nowruzi [7], A. Goldberg [8], T. Hoffmann [9], J. Davila-Montes [10], P. Rodríguez-Puente [11], J-B. Kim [12], T. Breban [13], R. Breeze [14], B. Szmrecsanyi [15].

The term is a two-way unit of language, which has a way of expression and a way of content, and linked with thinking, which reflects the dynamic process of human cognition of reality and forms human's knowledge. Therefore, an important task of linguistic modeling is the examining of cognitive reasons for the systematization of special knowledge, which is called «the cognitive dimension of our modern civilization» [16]. «The successful capture of this information is critical to help determine the most likely sequence of words spoken because it quantifies which word sequences are acceptable in a

\footnotetext{
${ }^{*}$ Corresponding author: discovery81@mail.ru
} 
given language for a given task and which are not. Thus, language modeling can be thought of as a way to impose a collection of constraints on word sequences» [17].

The method of linguistic modeling helps to build an integrative model of knowledge, which is based on linguistic and cognitive reasons. So it reflects the actual cognitive situation in an examined professional area. The modeling function of terminological units have been associated with the emergence of new concepts based on existing ones due to the convergence of related concepts, establishing a similarity between them [18].

Such classification is especially relevant at the present time for the subject construction generally, and for the names of building materials (NBMs) particularly. The study of lexemes and phraseological units of the NBMs is not as young but it is represented not only by construction terms, but also by other sciences, general scientific and various industrial terms, for example, chemistry, physics, mathematics, management and others

The NBMs directly depend on the development of the construction business, which is improved and filled with various progressive technologies under the influence of scientific and technological progress [19]. Due to the functional variety of terms and the increase of new terms it is difficult to establish systemic relations, which causes the necessity of the criteria for a logical and cognitive classification of concepts.

The goal of the research is to describe the cognitive model of the Russian and English NBMs and to compare the content structure of the studied terminological units. The analysis of the terms is based on a complex modeling of nominative and conceptual categories and includes various ways of criteria of the research like the cross-language equivalence. The last sense of matter is revealed in the researches of H. Zho [20], N.F. Khasanova [21], V. Vivaldi [22], A. Rosenbachn [23], P. Gamallo [24], A. Krzyzanowska [25], L. Sasu [26], J. Yuan [27], E.M. Ponti [28], W. Gladrow [29], N. Ilyushchenko [30]. It is the systematization of concepts that S.V. Grinev, allows to reveal the essential connections and relationships between concepts, to clarify the place of each concept in the conceptual system. "Systematization is carried out by classifying concepts, that is, representing them in the form of a system in which consecutive relations between them are fixed» [31].

\section{Materials and methods}

\subsection{Materials}

To select the corpus of lexical and phraseological units of the NBMs, construction documents, construction and explanatory dictionaries were studied. This represents the system of concepts of building materials. It should be noted that it is impossible to cover all the facts in one study. Therefore, the presented research has been carried out with the help of the continuous sampling and partial selection used for the study of the vocabulary entries from the scientific and technical dictionaries in the field of construction. The authors have analyzed 1259 NBMs of the Russian terminology and 1427 NBMs of the English terminology. The following mono- and bilingual dictionaries have been chosen as the source of data for study: Cambridge Dictionary, Comprehensive Russian-English scientific and technical dictionary, Oxford Illustrated Dictionary [32], Complete English-Russian Polytechnical Dictionary M.V. Adamchick [33], Complete Englisn-Russian Dictionary (V.K. Müller), English-Russian Praseological Dictionary (P.P. Lytvinov), Russian Language Explanatory Dictionary (S.I. Ozhegov), Terms of Russian Architectural Heritage (V.I. Pluzhnikov), Visual Dictionary of Architectural Styles (O. Hopkins), and the works of S. Meral [34], I.B. Lykov [35] 


\subsection{Research methods}

The method is based on the consecutive identification. The classification of the NBMs was carried out in few stages through a comprehensive analysis of lexical and phraseological units according to different paradigmatic aspects. The research represents the comparative and typological description of the data based on the analysis and synthesis of the major achievements of the modern linguistics. The continuous sampling and partial selection methods applied for the study of the Russian and English NBMs from technical dictionaries have helped to form the experimental part of cognitive modeling in the Russian and English scientific and technical terminology. The component analysis has been used in the study of structure of the NBMs. The authors have used the method of equivalent comparison of NBMs as well.

\section{Results}

The authors have revealed semantics of the NBM of Russian and English languages applying the definitional method of component analysis, generic and descriptive analysis, which allowed to establish a connection between concepts and compared a genus, aspects and meanings of lexemes and phraseological units. That is the comparison of the value of hyperonyms with the meanings of hyponyms to regard synonymy, antonymy, incompatibility. The structure of the concept of the NBMs can be fully represented in the form of diagrams based on three features, representing all the variety of categories of construction objects. The NBMs are the central concept of the construction sphere, the structure of which is determined by the cognitive features: function, structure, space, shape, size, time, objectifying all the necessary structural, functional, spatial and quantitative characteristics of a given terminological area.

The thesaurus approach is used to define the thematic component. For example, the terms form groups that will be oriented by properties and are hierarchically arranged, by means of semantic deployment, or stepwise identification, definitions and substitutions were decomposed into the definitions of interpretations of individual components: groups and subgroups. As a result, definitions were defined for groups with a simpler relationship between form and content, for their subsequent comparison. The applied result of this study is a model that integrates features of different types of dictionaries (translation, terminological, ideographic, explanatory, educational), which, in our opinion, reflects the thesaurus nature of the study.

\section{Discussion}

\subsection{The internal structure of the NBMs}

The NBMs have a compound thematic foundation. The material component is generic to more dissimilar terms. Consequently, the structure of this model can be presented in several stages. Each group is formed from the term 'materials' and consists of the largest number of groups. The principle of constructing the topical groups is hyponymic, which is supported by generic relations at all levels. The structure of the studied groups has the following regularity: from the core to the periphery, the number of semantic features of these concepts, represented in a separate terminological unit increases: meanings of the components become more frequent and thus dependent on the context.

The term 'materials' as a large field related to all terminological definitions of different thematic groups have united by the 'materials' as a component and have formed an 
extensive, well-structured group. We considered the internal organization of this group and define its core. For example, the core of the field is the noun 'material' and its lexical synonyms are in Table:

Table The noun 'material' and its lexical synonyms.

\begin{tabular}{|l|l|l|l|l|l|}
\hline \multicolumn{5}{|c|}{ material } \\
\hline substance & component & a type of physical thing & equipment & matter & mixture \\
\hline
\end{tabular}

The authors considered a step-by-step diagram of the internal structure of the NBMs, the definitional components of which have been divided into the smallest components. For example, geotextile or fabric - a lining roll material. One of the types of geosynthetics; geofabric, made by needle-punched, thermally bonded or hydro-bonded methods from polypropylene and / or polyester threads (from one endless thread, or from 5-10 cm scraps):

lining $\rightarrow$ a material or substance that covers the inside surface of something;

roll $\rightarrow$ to move somewhere by turning over and over; etc.

Below is the diagram of an internal structure of 'anchor strab' (Fig. 1).

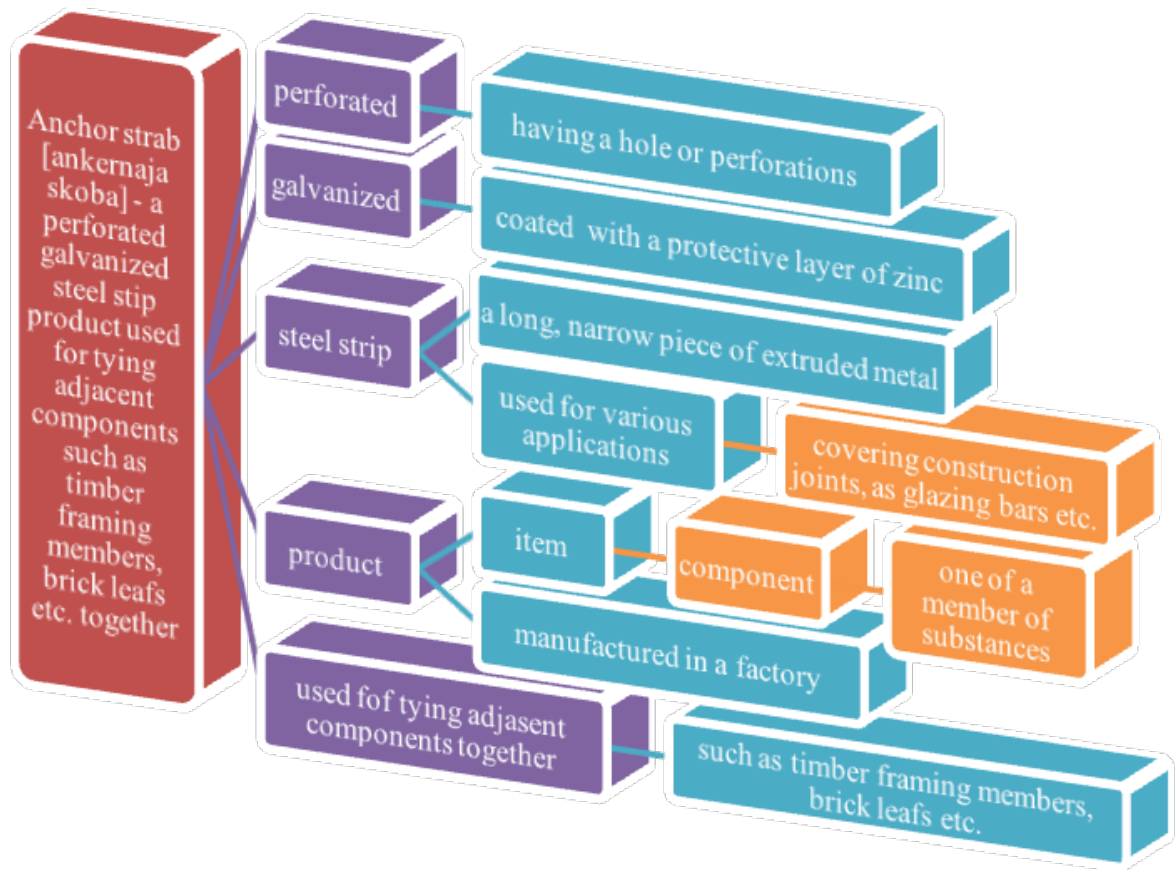

Fig. 1. The diagram of an internal structure of 'anchor strab:'

\subsection{Classification of the NBMs according to their types and properties}

The group «building materials and products» / «stroitel'noe materialovedenie» reflects the basic classification of building materials according to the type of the main constituent substance and their properties. Five groups have formed their hierarchical structure. These are: 
1. Organic materials / organicheskie materialy: wood, straw, bamboo, cellulose insulation, clay, natural paints and oils or waxes;

2. Inorganic materials / neorgonicheskie materialy: natural stone, obtained as a result of mechanical processing of rocks, and artificial ones as ceramics, metals and mineral binders;

3. Metals and metal products / metally i izdelija iz nih: structural steel, I-beam, column, rebar, wire rope cabels;

4. Others building materials / prochie stroitel'nye materialy: glass;

5. Properties of building materials / svojstva stroitel'nyh materialov. The subgroup «properties of building materials» is subdivided into lower level frames based on the conceptual characteristic: physical properties / fizicheskie svoystva, mechanical properties / mehanicheskie svoystva, defects / defekty.

\subsection{Semantic characteristics of the NBMs}

The first step of the periphery of the analyzed field is represented by a terminological group, which has a colligate character related to all the selected components, which can be distributed into several semantically lower subgroups according to their differentiations:

1. Names of attributes of the assembly of materials / Naimenovaniya priznakov sovokupnosti materialov;

2. The name of the attributes of one of the constituent substances or components / Naimenovaniye priznakov odnogo iz sostavlyayushchih veshchestv ili elementov;

3. Names of characteristics of materials / Naimenovaniya harakteristiki materialov;

4. Names of various chemical compounds and building combinations / Naimenovaniya priznakov razlichnyh himicheskih i stroitel'nyh soyedineniy.

The second step of periphery of the considered field is made up from lexical and phraseological units of the following groups:

1) the names of the features of structures, which are hyperonyms for groups, denoting various structures and their components: structure and construction / soruzhenie $i$ zdanie;

2) a group of lexemes and phraseological units including varieties of products: component and item / komponent i podpunkt

3) components of features and properties / komponenty, oboznachayushchiye svojstva;

4) components denoting to a chemical compounds / komponenty, oboznachayushchiye himicheskie sostavy;

5) names of features of inorganic compounds / naimenovaniya priznakov neorganicheskih soedineniy;

6) names of features of organic compounds / naimenovaniya priznakov organicheskih soedineniy;

7) names of compounds' features of calcium and oxide / naimenovaniya priznakov soedineniya kal'tsiya oksida.

This field is the most productive one and contains the largest number of terms. For example, see Fig. 2. and Fig. 3. 


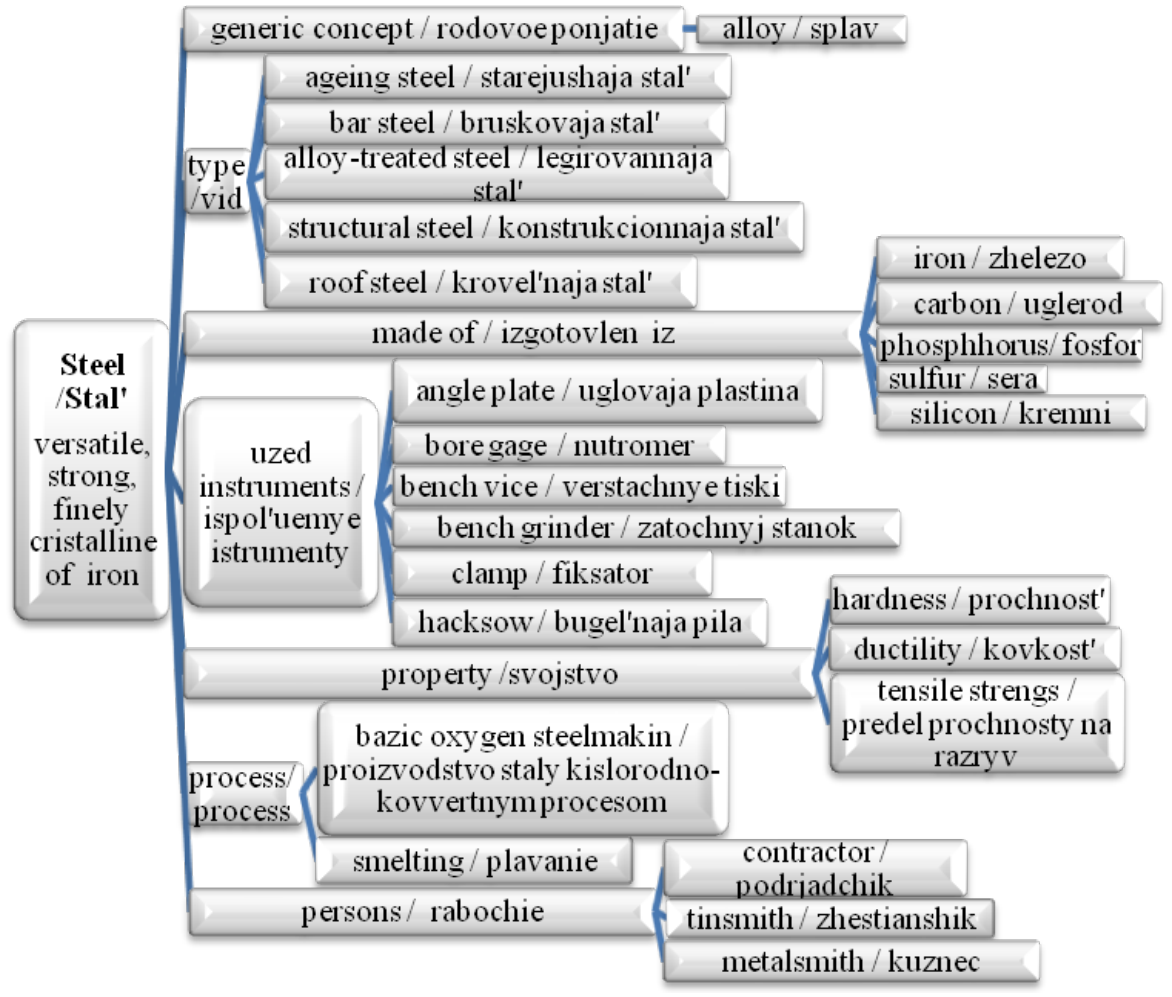

Fig. 2. 'Steel'.
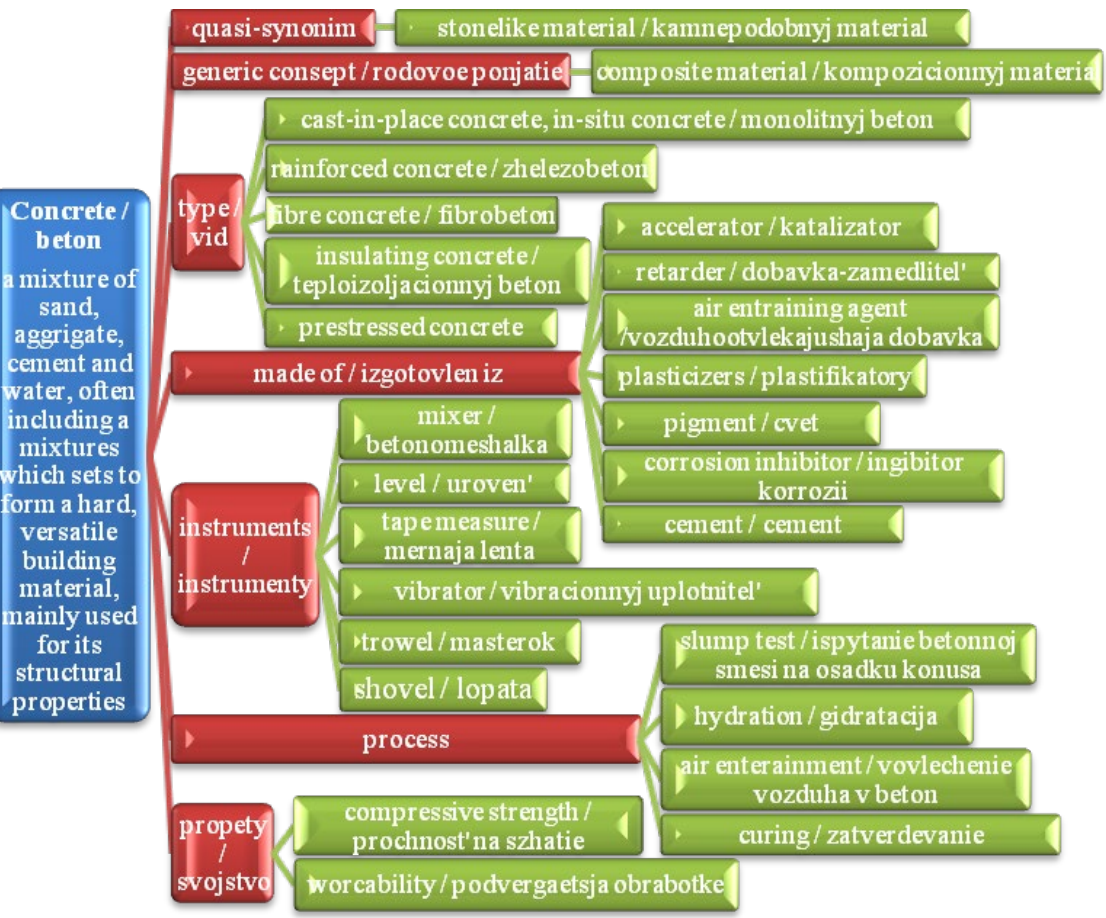

Fig. 3. 'Concrete'. 


\section{Conclusions}

The authors have examined the internal organization of the Russian and English NBMs, which consists of a number of topical units of construction, belonging to an extensive thematic area and reflecting the conceptual, subjective or functional properties of the designated facts.

This classification have reflected the usual way of the building of the terms and based on the decomposition of definitions of terms that have formed according to the professional development and have reflected the cognitive attitudes of the professional linguistic personality. The classification of lexical and phraseological units of the NBMs reveals a close connection with the history of development of the construction industry. The more complicated concepts have formed on the background of the most general and simple concepts, which is directly related to improvement of the construction process. This is due to the increasing process of the emergence of new terms related to the progress in construction. For example, the discovery and existence of chemical elements caused the emergence of such more complex and complicated substances as asbestos, gypsum, glass, etc. That's why the NBMs are multidimensional and have divided into subgroups of different levels.

The presented research has given the authors an opportunity to accomplish the cognitive classification of the Russian and English NBMs in the form of thematic groups, which consists of several stages, and to create several levels of their structure. This structure approaches the concept of the cognitive model of the term being developed in modern terminology. The proposed model of the Russian and English NBMs can find the application as the basis for ideographic dictionaries.

\section{References}

1. A. V. Spirov, E. M. Myasnikova, Linguistic modeling of gene regulation: Tradition from the language of experiments to the language of modeling, ICT Express 5(3) 182$186(2019)$

2. S. Khudanpur, Putting language back into language modeling, Spoken Lang. Reco. Understanding (2000)

3. R. Rosenfeld, Two decades of statistical language modeling: Where do we go from here, Spoken Lang. Reco. Understanding (2000)

4. T. Hoffmann, T. Burner, J. Horsch, English comparative correlative constructions: A usage-based account, Open Linguistics 6 (1) (2020)

5. A Katherine, Effects of corpus-based instruction on phraseology in learner English, Language Learning and Teaching 21(3), 195-216 (2017)

6. J. Kamali, Typology of scaffolding in teacher discourse: Large data based evidence from second language classrooms, International Journal of Applied, 30(2), 329-343 (2020)

7. M. Nowruzi, J. Kamali, The instruction of meta-cognitive listening strategies and its impact on listening performance of high and low-test-anxious intermediate learners, Journal of Studies in Learning and Teaching English, 2(1), 15-40 (2013)

8. A. Goldberg, Constructions: a new theoretical approach to language, TRENDS in Cognitive Sciences, 7(5), 219-24 (2003)

9. T. Hoffmann, English Comparative Correlatives: Diachronic and Synchronic Variation at the Lexicon - Syntax Interface (Studies in English Language, Cambridge University Press, 2019)

10. J. Davila-Montes, Enthymeme, metonymy and method: comparing genre-bound rhetorical deviations between languages through corpus studies, Language and 
Intercultural Communication 19(5), 407-420 (2019) DOI: 10.1080/14708477.2018.1545779

11. P. Rodríguez-Puente, The English phrasal verb, 1650 - present: History, stylistic drifts, and lexicalisation (Studies in English Language), (Cambridge: Cambridge University Press, 316-321, 2019). DOI: 10.1017/9781316182147

12. J. Kim, English comparative correlative construction: interactions between lexicon and constructions, Korean Journal of Linguistics, 36(2), 307 (2011)

13. T. Breban, Proper names used as modifiers: A comprehensive functional analysis, English Language and Linguistics, 22(3), 381-401 (2018) DOI: $10.1017 / \mathrm{S} 1360674316000514$

14. R. Breeze, Corpora and computation in teaching law and language, International Journal of Language \& Law, 6(1-7) (2017) DOI: 10.14762/j11.2017.001

15. B. Szmrecsanyi, B. Douglas, E. Jesse, F. Karlien, Toward more accountability: Modeling ternary genitive variation in Late Modern English, Language Variation and Change, 28(1), 1-29 (2016) DOI: 10.1017/S0954394515000198

16. M. Popescu, Knowledge Modeling and Terminology Studies in the Field of Engineering, The 14th International Conference on Applied Computer Science, Cambridge (MA), January 29-31, 257 (2014)

17. J. R. Bellegarda, Exploiting latent semantic information in statistical language modeling, Proceedings of the IEEE, 88(8) (2000)

18. Wu Cx, J. Baccanello, Using Contrastive Terminology Analysis in Teaching a Foreign Language, Journal of Applied Linguistics 5 (3), 461-471 (2019)

19. T. Hoffmann, Construction grammar as cognitive structuralism: the interaction of constructional networks and processing in the diachronic evolution of English comparative correlatives, English Language and Linguistics, 21(2), 349-373 (2017)

20. H. Zho, Making a stance: social action for language and intercultural communication research, Language and Intercultural Communication 20 (2), 206-212 (2020)

21. N. Khasanova, I. Kuznetsova, M. Gulkanyan, The equivalence of the Russian and english phraseological terms in the field of construction and architecture, IOP Conference Series: Materials Science and Engineering, 890 (2020) DOI:10.1088/1757899X/890/1/012213

22. V. Vivaldi, J. Zulategui, The Wished Formulas: A contrastive Analysis between Standard Spanish and German, Linguistica Pragensia 29(1), 47-66 (2019)

23. A. Rosenbachn, On the (non-)equivalence of constructions with determiner genitives and noun modifiers in English, English Language \& Linguistics 23(4), 759-796 (2019) doi: $10.1017 /$ S1360674319000273

24. P. Gamallo, S. Sotelo, J.R. Pichel, M. Artetxe, Contextualized Translations of Phrasal Verbs with Distributional Compositional Semantics and Monolingual Corpora, Computational Linguistics 45(3), 395-421 (2019) DOI: 10.1162/COLI_a_00353

25. A. Krzyzanowska, Comparative analysis of linguistic terminology: case of french and polish phraseology, Roczniki humanistyczne 65 (8), 117-129 (2017)

26. L. Sasu, Comparative-contrastive analysis of Romanian-English translation of verb phrase structures, $4^{\text {th }}$ International Conference on Theoretical and Applied Linguistics Structure, Use and Meaning: (Re/De) Contextualisation, 311-322 (2017)

27. J. A. Yuan, Comparative Study of English and Chinese Ditransitive Constructions. North East Asia International Symposium on Linguistics, Literature and Teaching, 237243 (2018)

28. E. M. Ponti, O. Helen, Y. Berzak, I. Vulić, R. Reichart, Th. Poibeau, E. Shutova, A. Korhonen 2019 Modeling Language Variation and Universals: A Survey on Typological Linguistics for Natural Language Processing Computational Linguistics 45(3), 559-601 DOI: 10.1162/COLI_a_00357 
29. W. Gladrow, E. Kotorova, Contrastive Examination of Speech Handling Patterns, Zeitschrift fur Slawistik 62(3), 365-386 (2017)

30. N. Ilyushchenko, Comparative Study of English and Russian Phraseology: Component Theory of Identity and Difference of the Seme Organization, Journal of Language \& Education 3(1), 75-84 (2017) DOI: 10.17323/2411-7390-2017-3-1-75-84

31. S.V. Grinev, Vvedenie v terminografiyu [Introduction to Terminology Studies] (MPU, 1995)

32. Oxford Illustrated Dictionar, (Dorling Kindersley Limited and Oxford University Press, 2002)

33. M. V. Adamchick, Complete English-Russian Polytechnical Dictionary, (AST, 2004)

34. S. Meral, E. Kishali, A Study on the Intersection of Architectural History and Architectural Conservation: Uskudar Semsi Ahmed Pasa Complex Artsanat 13, 313-334 (2020)

35. I. B. Lykov, T. V. Popova, Macrostructure of special online russian dictionaries of architecture and construction: general characteristics. $3 d$ International Multidisciplinary Scientific Conferences on Social Sciences and Arts, SGEM 4(2), 375381 (2016) DOI: 10.21122/2309-4923-2018-4-74-82 